\title{
18TH CENTURY VISTULA RIVER GEOGRAPHY IN VIEW OF FRANCISZEK FLORIAN CZAKI'S MAPS
}

\author{
KRZYSZTOF STRZELECKI \\ Institute of Geography and Regional Studies, Pomeranian University in Słupsk, Słupsk, Poland
}

Manuscript received: April 24, 2012

Revised version: February 8, 2013

Krzysztof Strzelecki, 2013. 18th century Vistula river geography in view of Franciszek Florian Czaki's maps. Quaestiones Geographicae 32(1), Bogucki Wydawnictwo Naukowe, Poznań, pp. 27-32. 3 figs. DOI 10.2478/quageo-2013-0004, ISSN 0137-477X.

AвSTRACT. Old maps are proven to be very useful when it comes to solution of the modern research problems and are widely used in various science disciplines connected with specification of mutual relations between elements of the geographical environment. This fact stems from the increased consciousness of unique information recorded on old maps, which at their time constituted a basis for subsequent cartographical studies. The geographical characteristics of the Vistula river were depicted in a handwritten 12-sheet map made the first half of the $18^{\text {th }}$ century by Franciszek Florian Czaki, a military cartographer. On the basis of his own terrain mapping, Franciszek Florian Czaki succeeded in creation of his work, which was intended to provide an example for the designed, detailed map of Poland, ordered by Józef Aleksander Jabłonowski, the Nowogród voivode, and later by the king Stanisław August Poniatowski. The map was fully based on terrain mapping, which included such details as: settlement, road and water networks, forests, land relief as well as main types of ownership: crown-, church-, and nobility-owned.

KEY wORDS: the Vistula, old maps, 18th century, Franciszek Florian Czaki

Krzysztof Strzelecki, Institute of Geography and Regional Studies, Pomeranian University in Stupsk, 22A, Arciszewskiego St., 76-200 Stupsk, Poland, e-mail:krzycho.strzelecki@gmail.com.

\section{Introduction}

Political changes in the country and Europe in the second half of the 18th century greatly influenced the new development of Polish cartography. The increased importance and purpose of maps for the country's defensive capabilities as well as the necessity of economic reforms determined a new direction for the elaboration of the detailed map of Poland. Most of the works of this period in this field belong to Franciszek Florian Czaki, one of the most prominent Polish cartographers (died in 1772). Franciszek Florian Czaki comes from Csaky de Kerestszegh, a Hungarian noble family, which emigrated to Poland in 1711. Initially, Franciszek served in the Sass artillery where he achieved the rank of a captain (Buczek 1939). At that time, cartography was a domain of the military, which hired special units for measurement works. 


\section{Activity and cartographical achievements of the Vistula map author}

F.F. Czaki's works in the field of Polish cartography date back to 1740 , the first presumably being the works on the "Sarmatia Atlas" (Atlas Sarmacji) under the protectorate of Earl Jan Maurycy Brühl (1693-1755), to whom he dedicated his only map under his name, a map of Spiš district (Starostwo Spiskie) scaled 1:167 000 according to the engraving of Fryderyk Hampe of Elbląg (Jakubowski 1930, Olszewicz 1932, Krassowski 1982). On the basis of his own terrain measurements F.F. Czaki also drew up a map of the Warsaw area, scaled 1:70 000, oriented to the south (Olszewicz 1932); 12-sheet Vistula map, scaled 1:180 000 (Fig. 1 and 2); as well as maps of certain crown voivodeships, which went missing except for a 3-sheet Volyn map, scaled 1:263 000, published anonymously by J. L. Le Rouge in Paris in 1769 (Buczek 1939).

Since 1760 Czaki had been working for Józef Aleksander Jabłonowski (1711-1777), Nowogród voivode, on a multi-sheet map of the entire Poland. Czaki, however, did not finish the map because in 1765 he began his service for the king Stanisław August Poniatowski (1732-1798) together with all his cartographical works (about 200 maps). Soon after the retrieval of maps taken by Czaki, Jabłonowski decided to hand his materials to G.A. Rizzi-Zannoni (1736-1814), an Italian cartographer, who on the basis of Jabłonowski's materials and a 10-year-work developed "The Great Map of Poland" (Carte de la Pologne ...) in 1772 (Olszewicz 1921, 1932).

As a crown artillery captain and court cartographer, Czaki joins the cartographer's team lead by Karola de Perthées (1740-1815). King's intent was drawing up and developing of a complete, detailed map of the entire country (Olszewicz 1930). At this time, F.F. Czaki elaborated a detailed map of the lower course of the Vistula, scaled 1: 30300 (Midzio 1969, Szeliga 1982); as well as made maps of Bydgoszcz areas. The former was made in relation to the planned Vistula-Noteć canal (1766). Each year from 1766 to 1772, Czaki travelled to Lithuania where he collected topographic materials for maps developed in Warsaw. Also in Lithuania Czaki supervised works regarding the Niemen river cleansing and its adjustment for sailing. Shortly before his death, c.a. 1770, F.F. Czaki completed the economic map of Brzeg for the king. F.F. Czaki also completed a Pina-Muchawiec canal, which he illustrated with a map of 1772 (Buczek 1939) as well as took part in drainage of Pinan mires (Olszewicz 1932). The major part of Czaki's work was often used as a source cartographical material by many later cartographers, e.g. J. L. Le Rouge, G.A. Rizzi-Zannoni, K. Perthées, F.T. Pfau, B. Folino.

\section{The content range of the Vistula map}

At the time of its development, the 12-sheet Vistula map of F.F. Czaki of 1760 was not met with a complex scientific discussion and was not a subject of deeper analyses. Information provided in a short descriptive form on the map was to be found in publications of old cartography synthesis character carried out, among others, by Olszewicz (1921), Buczek (1963) and Szeliga (1982). To visually bring closer the usefulness and possibility of utilisation of Czaki's Vistula map for the assessment of the state of and changes to the environment, reproductions of map sheets were ordered from the National Library of France (Gallica). The complete study consists of twelve separately colourful handwritten maps sized $55.0 \times 42.0 \mathrm{~cm}$. In total the sheets cover the Vistula river valley from its spring to its mouth. Basically, the work does not hold a general title because each sheet has its own title and except for the subsequent numbers, the sheets also contain the information of the enclosed area or a part of the voivodeship. Nevertheless it is possible to recognize the repetition of the phrase: "Carte Geographique de la Vistule". K. Buczek (1963) suggests that the map is a part of some certain map or set of maps enclosing bigger areas or even whole voivodeships, on which Czaki worked on between 1740-1760 (Marcel 1907). This assumption is confirmed by the structure of the maps (Fig. 1 ), which are covered by drawings whereas the content was not limited to the terrain directly adjacent to the areas along the Vistula river valley.

The legend was embedded within the map content with the help of cartouches with abun- 


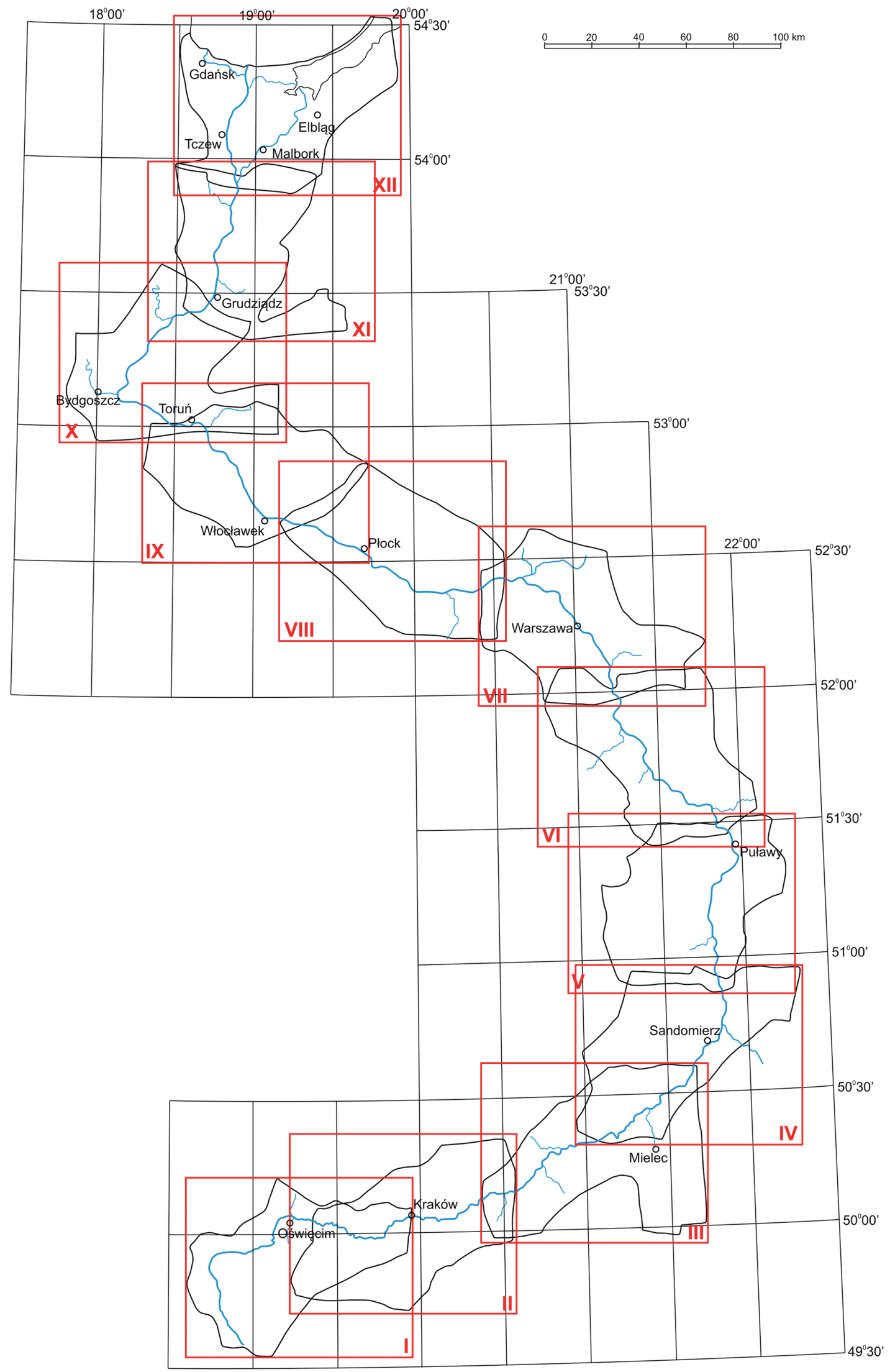

Fig. 1. Spatial coverage of map sheets and particular map sheets overlay of F.F. Czaki's Vistula river map. 
dantly ornamented parerga of undoubted artistic value. For instance, to highlight the mountainous character of the area in sheet no. 1, a title text was placed in the bottom right corner laid on a picture of a rock face, above which, in higher mountain area, two children are engrossed in shearing of a sheep. On the left side there is a picture of crops presenting a pumpkin in a companion of laid out pear tree, apple tree, plum tree twigs, a laying grain sheaf as well as domed beehive in a shape of a bell, made of woven straw, out of which bees are flying out. From the West side of the picture there is a highlander with a shepherd's axe against a grazing mountain chamois. At the mountain foot on the left side, two silhouettes of standing hunters with a dog and a wild hunted game. Contemporary clothes of the hunters and belted on sabres indicate that they belong to the Polish nobility. On the right side, among various kinds of fishing nets and a trident leaning against a rock, a figure of a bearded old man with a wreath on his head moves the rocks away, out of which the water springs. This man symbolises the Roman god, Neptune, referring to the Vistula spring area presented on the map sheet whereas the scene displaying three children occupied in fishing highlights the great importance of ponds abundant in fish and crayfish utilised from the $12^{\text {th }}$ century (Fig. 2).

Symbol system is unified for all sheets and is described in Latin. The characteristic feature of Czaki's map is the highlight of various kinds of ownerships with the help of colours. Golden line

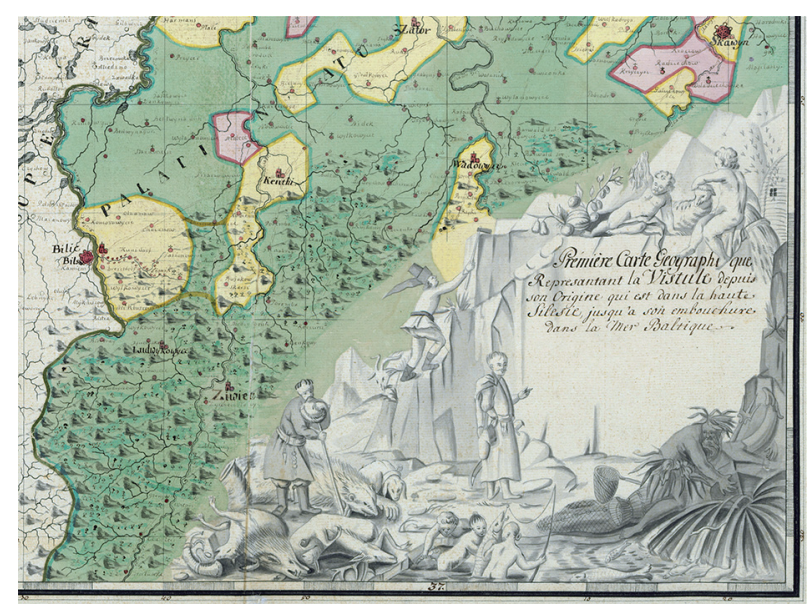

Fig. 2. Ornamental parerga and a part of the Żywiec Beskids (Beskid Żywiecki) together with Silesian Foothills (Pogórze Śląskie) on map sheet no. 1 (original copy scaled down). separates one voivodeship from another, yellow colour highlights the crown properties, red colour church properties, blue colour land properties, and green colour counties.

Settlement elements presented on the map include: town with defensive walls (Urbes Moenibus Cincta), towns without defensive walls (Willa Sine Moenibus), villages with temples (Pagi Cum Templo), villages without temples (Pagi Sine Tempo) villages and manors of the nobility (Pagi et Nobilium Palacia), monasteries (Monasteria), villages stretched along the road (Pagi Longo Tractu Excurrentes), village houses dispersed in various places (Domus Rustica Sparsim Posito), inns, taverns, roadhouses (Diversoria), mills (Molendina) and castles (Arces). The legend does not include highlighting of physiographic objects, in particular, highlighting of rivers, lakes, ponds, forests and land relief.

Landforms are presented in a perspective view of old mounds' maniera, also called molehills or clods (Pietkiewicz 1930, Szaflarski 1965, Saliszczew 1984, Pasławski 2006). Mountain shading is visible on the right side as if the light came from the left side of the map. Land relief drawing indicates superficiality and lack of terrain studies from the autopsy and it should be treated as a separate sketch. Spatial dispersement of hillock groups was used for the representative lay out of the Silesian Beskids. No mountain massif was named.

The Vistula river basin constitutes the main hydrographical element on the presented map sheets. Although Czaki made extensive effort for the representation of the drainage system, this work cannot be classified to the hydrographical map group (Olszewicz 1932). Numerous tributaries of first, second and even third order were not meticulously described. River names are often misspelled, e.g. Wysla (Wisła), Swyder (Świder), Harta (Skrwa). The bed of the Vistula valley, outlined on the map by two thick lines, conveys the strongly meandering river path in a characteristic way, between which thinner lines signalise the complexity of the river course. Other major rivers are highlighted by two close lines whereas little watercourses by a slightly wavy line, emphasising their sinuosity and improving their legibility. Although the character of the upper Vistula river system and general flow of the river together with the main tributaries was made appropriate- 


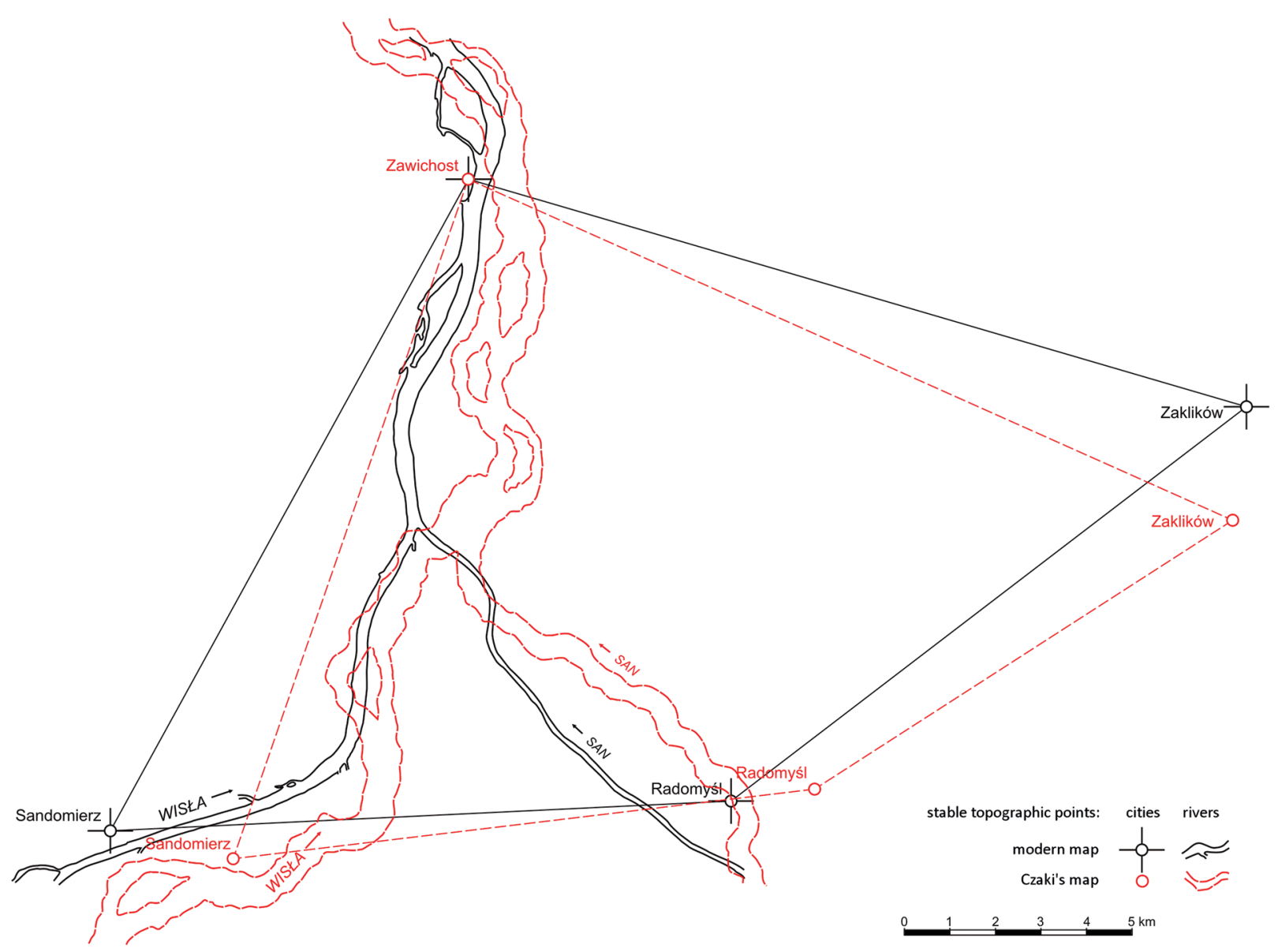

Fig. 3. Vistula course on F.F. Czaki's map and modern map.

ly in comparison to a modern map, sometimes it is moved in relation to the cartographic grid or the settlement network (Fig. 3).

The lakes were highlighted more prominently on map sheet no. 1, 11 and 12. The lakes are not named and in comparison to the modern topographic map scaled 1:100 000 it is possible to see considerable changes to their shape and location. Lake surfaces were lined by mean of thin horizontal lines, thickened by a lake shore. This method was also used for shoreline mapping of the Baltic Sea and the Vistula Lagoon. Forests and big groups of trees are stretched on coloured areas of the owned lands without clear borders and are represented by densely drawn symbols of similar deciduous trees. Although one can say that the outlines of the big forest clusters have not changed, on Czaki's map they constitute tighter complexes. Communication network on the map sheets is not detailed. The network consists of main roads of national character, marked by double lines, connecting only the bigger towns.
Handwritten map contains inscriptions, style and size of which was adjusted to the size and importance of geographical objects. The map is characterised by sufficient mutual contrast and legibility. The names of big areas were written by mean of exapanded majuscule antiqua in Latin of $6 \mathrm{~mm}$ size. Towns' (4 mm size), villages' and rivers' names (2 mm size) are inscribed in a type of cursive writing, italic type, and are capitalised. Without referring to the etymology and toponymy in historical view, town names follow the rules of the Polish language. Town names, however, are distorted in comparison to the modern spelling of geographical names, e.g. Bieron (Bieruń), Bilic Bilsk (Bielsko-Biała), Kentki (Kęty), Ludwykowyce (Łodygowice), Oswieczym (Oświęcim), Skawyn (Skawina), Toruin (Toruń), Wraclawek (Włocławek), Ziwiec (Żywiec). Some cities are named according to the German spelling, e.g. Ples (Pszczyna), Mariwerder (Kwidzyn), Skotschau (Skoczów) or Latin spelling, e.g. Cracovia (Kraków). 


\section{Conclusion}

This map, as one of the lesser known works of F.F. Czaki was intended as an example for the development of the map of entire Poland, works of which began in 1740 by Jabłonowski. Ultimately, the Vistula map was not published. One of the reasons for that could have been critical remarks of J.B. d'Anville, a French cartographer, made in 1761 as to the indication of geographic coordinates. Although from executed calculation it seems that the coordinates errors do not exceed the value of a few minutes (Buczek 1963, Szeliga 1982, Strzelecki 2007, 2008), it may be some reason for later parting of Czaki and Jabłonowski (Olszewicz 1932).

Developing identical methods of analysis of accuracy of former maps allowed for detailed and full recognition of the correctness of description of the 12-sheet cartographic image of the map of the Vistula River by F. F. Czaki. Based on the aforementioned method, it was also possible to express through cartographic methods of research the accuracy between chosen 18th century maps, as well as the degree of usefulness and the potential of using this map as the source material for a wide range of experts contemporarily dealing with changes in the environment in selected periods of time. The way the work by Czaki was of superior value in the 18th century, it is nowadays a unique and treasured monument of the national legacy, which should fulfill an important part in further research on the level of thorough understanding of the cartographic image of former and present Polish lands.

\section{References}

BuczeK K., 1939. Czaki Franciszek Florian. In: Polski Stownik Biograficzny, 4: 161-162. Kraków.

BucZEK K., 1963. Dzieje kartografii polskiej od XV do XVIII wieku (The History of Polish Cartography from 15th to 18th century). Warszawa.
JAKUbOWSKI J., 1930. Nowo odnaleziona polska mapa Spisza (Recently discovered Polish map of Spiš). Pamiętnik II Zjazdu Stowiańskich Etnografów i Geografów w Polsce w 1927 r., 2: 255-256. Kraków.

KRASSOWSKI B., 1982. Wśród starych map i atlasów Biblioteki Narodowej w Warszawie (Among old maps and atlases of the National Library in Warsazw). Warszawa.

Marcel G., 1907. Correspondance de Michel Hennin et de d'Anville. Bulletin de Géographie Historique et descriptive, Imprimerie Nationale Paris, 3: 454-482.

Midzıo J., 1969. Mapa dolnego biegu Wisły F.F. Czakiego (Czaki's map of the lower course of the Vistula river). Polski Przeglad Kartograficzny, 1(3): 15-18.

MiDzıo J., 1972. Prace kartograficzne Franciszka Floriana Czakiego, kartografa polskiego XVIII wieku (Cartographic works of Franciszek Florian Czaki, Polish cartographer of the 18th century). Polski Przeglad Kartograficzny, 4(4): 151-157.

MıDzıo J., 1978. Franciszek Florian Czaki, kartograf i inżynier w XVIII wieku (Franciszek Florian Czaki, the ethnographer and engineer of the 18th century). Mówiq wieki, 8.

Olszewicz B., 1921. Polska kartografia wojskowa. Zarys historyczny (Polish Military Cartography. Historical Outline). Warszawa.

Olszewicz B., 1932. Kartografia polska XVIII w. Przeglad bibliograficzno-historyczny (Polish Cartography of the 18th century: Bibliographical and Historical Overview). Lwów.

PASŁAWSKI J., 2006. Wprowadzenie do kartografii i topografii (Introduction to Cartography and Topography). Nowa Era, Wrocław.

PietKIEWICZ S., 1930. O sposobach przedstawiania terenu na mapach (About the methods of terrain mapping). Bibljoteka Stużby Geograficznej, 5. Główna Drukarnia Wojskowa, Warszawa.

SAliszczew K.A., 1984. Kartografia ogólna (General Cartography). PWN, Warszawa.

SZAFLARSKI J., 1965. Zarys kartografii (An Outline of Cartography). PPWK, Warszawa.

StRZELECKI K., 2007. Charakterystyka geograficzna Wisły na podstawie 12-arkuszowej mapy F.F. Czakiego z pierwszej połowy XVIII wieku (Geographical Characteristics of the Vistula river on the basis of 12-sheet map of F.F. Czaki of the first half of the 18th century). Nauki Geograficzne w Badaniach Regionalnych, Kielce, 1: 205-221.

StrZelecki K., 2008. Wisła na mapie Franciszka Floriana Czakiego z drugiej połowy XVIII wieku (Wisla River on the F.F. Czaki's map from the first half of XVIII century). Stupskie Prace Geograficzne, 5: 93-100. Wydawnictwo Naukowe Akademii Pomorskiej, Słupsk.

SzeLIGA J., 1982. Rozwój kartografii Wybrzeża Gdańskiego do roku 1772 (The Development of the Cartography of the Coast of Gdańsk to 1772). Wrocław.

SzeligA J., 1993. Metody i stan dokładnościowych badań dawnych map z obszaru Polski (Methods and state of the accuracy research of early maps of Poland). Dorobek polskiej historii kartografii, Warszawa: 51-67. 